\title{
A clinical study to evaluate the effectiveness of the short proximal femoral nail in the management of unstable intertrochanteric fractures
}

\author{
Ahmed Rayan Jelani, Mohammed Ismail Hathiwale*, \\ Vishwas Vittal Mundewadi, Owais Ahmed
}

Department of orthopedics, Al Ameen Medical college vijayapura, Karnataka, India

Received: 25 October 2018

Revised: 15 January 2019

Accepted: 17 January 2019

\section{*Correspondence:}

Dr. Mohammed Ismail Hathiwale,

E-mail: ismailtusker@yahoo.com

Copyright: ( ) the author(s), publisher and licensee Medip Academy. This is an open-access article distributed under the terms of the Creative Commons Attribution Non-Commercial License, which permits unrestricted non-commercial use, distribution, and reproduction in any medium, provided the original work is properly cited.

\section{ABSTRACT}

Background: The objective was to study the effectiveness and drawbacks of short proximal femoral nail in the management of unstable intertrochanteric fractures.

Methods: This prospective study was conducted in the department of orthopaedics Al-Ameen medical college, Vijayapura, Karnataka, India from July 2010 to June 2017. Total 175 patients (130 males and 45 females) aged between 41 to 80 years with unstable Intertrochantreric fracture (155 had type IV and 20 had type III according to Boyd and Griffin classification). All patients were operated using Short proximal femoral nail and followed at least for a minimum period of 6 months and were evaluated radiologically and clinically by Kyle's Criteria.

Results: Anatomical reduction was achieved in 125 patients, $105(60 \%)$ had no complications post operatively. Complications included 5 cases of avascular necrosis and screw cut out, 5 cases of delayed union, 5 cases of Z-effect, 20 cases of varus malunion, 10 cases of antirotation screw breakage, 5 cases of distal bolt breakage and 15 cases with lateral thigh discomfort. 125 patients had No shortening and the average shortening was $0.34 \mathrm{~cm}$, average time of union was 19.26 weeks (15-30 weeks) in 170 cases. At the end of 6 months, good to excellent results were seen in $71.5 \%$ of cases, $57 \%$ patients returned to their pre injury functional level.

Conclusions: Short proximal femoral nail provides good fixation for unstable intertrochanteric fractures, if proper pre-operative planning, good reduction and surgical techniques are followed leading to high rate of bone union and minimal soft tissues damage especially for Asian patients with relatively small femora.

Keywords: Bone nails, Fracture fixation, Intramedullary, Hip fractures, Unstable inter-trochanteric, Short proximal femoral nail, Kyle's criteria

\section{INTRODUCTION}

One of the most common fractures to occur in elderly population is fractures around the hip. Among that intertrochanteric fracture is most routinely encountered. These fractures occur in elderly population because of the trivial trauma secondary to senile osteoporosis. As India is having large chunk of elderly population it is estimated that by 2040 the incidence may almost get doubled. ${ }^{1}$
More than $50 \%$ of intertrochanteric fractures are unstable. Unstable patterns occur more commonly with increased age and with low bone mineral density. ${ }^{2}$ The presence of osteoporosis in intertrochanteric fractures is important because fixation of the proximal fragment depends entirely on the quality of cancellous bone present. The surgical stabilization of unstable intertrochanteric fractures remains a persistent challenge. Dissatisfaction with the use of the extramedullary devices like the 
Dynamic Hip Screw in unstable intertrochanteric fracture patterns led to the evolution of intramedullary devices.

The DHS has several mode of failure, the most common being cutting out of the Lag screw from the femoral head. It is due to increased bending moment across the implant / fracture construct. Because of the lack of lateral cortical support in the unstable fractures the femoral head can collapse if there is excessive medial displacement of the femoral shaft. ${ }^{3}$ To overcome the difficulties encountered in the treatment of unstable fractures, trocchanteric entry intramedulary nails have been developed.

The main principle of trochanteric entry nail fixation is based on a sliding screw in femoral head fragment attached to an intramedullary nail. The nail has major advantage over a DHS from the biomechanical point of view including semi closed procedure and a shorter lever arm giving greater stability allowing rapid rehabilitation. ${ }^{4}$ The gamma nail was the first trochanteric entry nail introduced in 1988 and was designed specifically for the treatment of unstable fractures. ${ }^{5}$ It is cannulated with a proximal diameter of $17 \mathrm{~mm}$ and proximal valgus angle of 10 degree, it allows only static locking distally. However the gamma nail has been implicated with serious implant related complications such as iatrogenic femoral shaft fractures during nail insertion and therefore other intramedullary fixation devices have been introduced. The proximal femoral nail was developed in 1996 with a redesigned tip that decreases resistance during insertion and reduces bone stress significantly thereby decreasing the changes of fractures during intra and post-operative fractures of the femoral shaft. ${ }^{6}$ It also incorporates two proximal screws to improve the rotational stability of the proximal fracture fragment.

In 1996, AO/ASIF developed a new device Proximal Femoral Nail which has been useful in early mobilization and treatment of unstable peritrochanteric femoral fractures. In June 2004 the short PFN was introduced by Gadegone and Salphale, the Indian PFN has following modifications for the Indian population. It is having a smaller proximal diameter of $15 \mathrm{cms}$, the proximal 2 screws are $6.4 \mathrm{~mm}$ and $8 \mathrm{~mm}$. the distal bolts are $4.9 \mathrm{~mm}$, the nail has 6 degrees valgus bend proximally, it is available in short and long versions from 250 to $420 \mathrm{~mm}$ in length, available in 9 to $12 \mathrm{~mm}$ of distal diameter and neck-shaft angle of 125 to 135 degrees. In April 2010 gadegone and salphale concluded after reviewing outcomes of 100 Asian patients who underwent short proximal femoral nailing for stable and unstable intertrochanteric fractures, they concluded that short proximal femoral nail is superior implant for stable and unstable intertrochanteric fractures in terms of operating time, surgical exposure, blood loss and complications especially for patients with relatively small femora. ${ }^{7}$ The purpose of this study was to assess the effectiveness and drawbacks of one such intramedullary device, the short proximal femoral nail in management of unstable intertrochanteric fractures (as per Kyles criteria). ${ }^{8}$

\section{METHODS}

This study is a prospective hospital based study conducted in Al-Ameen Medical College Hospital Vijayapura, Karnataka state, India between July 2010 to June 2017, the study included 175 cases of unstable intertrochanteric fractures (Boyd and Griffin classification type III and type IV pattern). ${ }^{9} 130$ males and 45 females aged between 41 to 80 years, 155 had type IV and 20 had type III of injury, all were operated with short PFN which fitted into the inclusion criteria. The inclusion criteria were the patients who had been diagnosed of having unstable intertrochanteric fracture, radiologically confirming unstable intertrochanteric fracture, Boyd and Graffin type III and IV fracture patterns and the patient who were medically fit and were willing for surgery. Exclusion criteria were patients below the age of 20 years, patients with open fractures, pathological fracture and medical contraindication and surgery.

\section{Pre-operative assessment}

This preliminary assessment included details about the patient's medical history and his/her mobility and activities of daily living, mobility was assessed using Parker and Palmer mobility scores (Table 1). ${ }^{10}$

Table 1: Pre-operatve assessment using parker and palmer scores.

\begin{tabular}{|lllll|}
\hline & No Problem & With Aids & With help from Another & Unable to perform \\
\hline $\begin{array}{l}\text { Able to get about the } \\
\text { house }\end{array}$ & 3 & 2 & 1 & 0 \\
\hline Able to get out of house & 3 & 2 & 1 & 0 \\
\hline Able to go shopping & 3 & 2 & 1 & 0 \\
\hline
\end{tabular}

\section{Pre-operative planning}

Determination of neck-shaft angle was done on unaffected side on AP x-ray using a goniometer. Nail diameter was determined by measuring diameter of proximal diameter of proximal femur on an AP x-ray.
Approximate sizes of the compression and anti-rotation screws were measured in the neck region. A $10-15 \mathrm{~mm}$ smaller screw than compression screw was chosen for the antirotation screw to prevent Z-effect. ${ }^{11}$ A short PFN (180 $\mathrm{mm})$ was used in all cases. 


\section{Operative techniques}

The patients were taken up for surgery after obtaining written and informed risk consent and complication of surgery. Patients were given xylocaine test dose and tetanus prophylaxis. All patients were started on antibiotics, a third generation cephalosporin was administered via IV route prior to anaesthesia. All the patients were given spinal/epidural anaesthesia. The patient was placed supine on a fracture table with the unaffected leg flexed and abducted as far as possible. The operative leg was placed in traction. Closed reduction was achieved by traction and internal rotation primarily and adduction and abduction as required. In cases where reduction between difficulties, Steinman pins were used as joy sticks to reduce the fracture percutaneously. Reduction was verified in image intensifier with AP and lateral view. Reduction was considered well if the cortical congruence at calcar region was restored and if the displacement between the fragments did not exceed 2 $\mathrm{mm}$ in any projection. The ideal position for screw in the femoral neck was defined as being central on the lateral radiograph and central or inferior on the AP radiograph. ${ }^{12}$ Standard operative techniques which are recommended in the literature were used. ${ }^{13,14}$ Following parameter were recorded intraoperatively. The total time of surgery, type of reduction closed or with joystick, length of incision, implant details, radiation duration, intraoperative complication and quality of reduction.

\section{Post-operative protocol}

Third generation cephalosporin was given twice daily for 72 hour and appropriate prophylaxis against thromboembolism was also given in high risk patient. Analgesics were given as per patient compliance. Post-operative wound assessment was done on $2^{\text {nd }}, 5^{\text {th }}, 8^{\text {th }}$ post-operative day. All patients were encouraged to sit in the bed after 12 hours after surgery. Active isometric and isotonic quadriceps exercises were started from day 2, non-weight bearing ambulation was started from $3^{\text {rd }}$ day onwards, partial weight bearing from $3^{\text {rd }}$ week onwards, full weight bearing was started after radiological signs of union.

\section{Follow up}

Patients were followed up at regular intervals at 1.5, 3, 4 and 6 months for serial clinical and radiological evaluation. At every visit patients were assessed clinically regarding pain, limp, hip movements, walking ability, deformity and shortening. Clinical assessments were done using Klyle's criteria (Table 2). ${ }^{8}$ All patients were radiologically assessed for progression and time of union, fracture alignment and implant related complications. All patients after 6 months of follow up (after fracture union) were assessed clinically and functionally as per the following criteria. Patients were followed up for a minimum of 6 months and maximum of 1 year.
Table 2: Functional evaluation by Kyle's criteria.

\begin{tabular}{|ll|}
\hline \multirow{3}{*}{ Eutcome } & Criteria \\
\hline \multirow{4}{*}{ Good } & No or Minimum Limp \\
\cline { 2 - 2 } & Absence of Pain \\
\cline { 2 - 2 } & Rarely using a cane \\
\hline \multirow{3}{*}{ Fair } & Mild limp \\
\cline { 2 - 2 } & Mild occasional pain \\
\cline { 2 - 2 } & Full range of motion \\
\hline & Using a cane \\
\hline \multirow{3}{*}{ Poor } & Moderate limp \\
\hline & Moderate pain \\
\hline & Limited range of motion \\
\hline & Using 2 canes or walker \\
\hline & Wheelchair bound \\
\hline & Pain on any position \\
\hline
\end{tabular}

\section{RESULTS}

This study was a prospective hospital based study conducted in Al Ameen Medical College, Vijayapura between July 2010 to June 2017 which included 175 cases of unstable intertrochanteric fractures of femur (Boyd and Graffin classification of type III and IV fracture patterns) that were operated with short PFN. ${ }^{9}$ The mean age of patients were 65.91 years.

Table 3: Age wise distribution of cases.

\begin{tabular}{|lll|}
\hline $\begin{array}{l}\text { Age group } \\
\text { (years) }\end{array}$ & Number of patients & Percentage \\
\hline $\mathbf{4 1 - 5 0}$ & 15 & 8.6 \\
\hline $\mathbf{5 1 - 6 0}$ & 55 & 31.4 \\
\hline $\mathbf{6 1 - 7 0}$ & 40 & 22.9 \\
\hline $\mathbf{7 1 - 8 0}$ & 65 & 37.1 \\
\hline Total & 175 & 100 \\
\hline
\end{tabular}

\section{Mode of injury}

The most common mode of injury in the series was trivial fall in 140 cases, which accounted for $80 \%$ of cases followed by Road Traffic Accidents in 20 cases and fall from height in 15 cases.

\section{Type of fractures}

There were 20 cases of Type 3 Boyd and Griffin pattern and 155 cases of Type 4 fracture pattern.

\section{Surgical outcomes}

All the cases in our study were fresh fractures except 10 (more than 25 days old). The mean interval between trauma and surgery was 11.5 days. The delay was due to delay in arrival to the hospital, medical condition of the patient and associated injuries, until then the patients were kept on skeletal traction, the operating time was 
86.4 minutes (range of 40-180) with average length of incision $10 \mathrm{~cm}$ (8 to $15 \mathrm{~cm}$ range). Post-operative reduction was assessed according to Baumgaertner criteria modified by Fogagnolo et al. ${ }^{15}$ Good reduction was achieved in 125 patients (71.4\%). Acceptable was achieved in 50 patients due to severe communition.

Table 4: Sex wise distribution of cases.

\begin{tabular}{|lll|}
\hline Sex & Number of patients & Percentage \\
\hline Male & 130 & 74 \\
\hline Female & 45 & 26 \\
\hline
\end{tabular}

\section{Complications}

Out of 175 patients, 105 patients (60\%) did not have any complication, complication were seen in 70 patients. We had no superficial or deep wound infections. The following complications were encountered intraoperatively. In 5 patients iatrogenic medial cortex fracture occurred while inserting a nail, the fracture took an average of 5 month to units. Patients had greater trochanter splintering while inserting the nail. In 5 cases we noticed Avascular necrosis and cutting out of both superior screws. These cases had failed to unite. We noticed 5 cases of " $Z$ " effect around 15 months, antirotation screws were removed and compression screws were tightened, the fracture united at 6 months. In another 5 cases compression screws backed out at 6 weeks, this led to varus collapse. We noticed a total of 20 cases of varus malunion at 6 months, varus malunion was attributed to grade III and IV osteoporosis, severe communition of the fracture and early weight bearing. We noticed 10 cases of antirotation screw breakage at 3 months. But these cases went on to unite at 5 to 6 month respectively. 5 cases had static and dynamic bolt breakage at 5 months, fractures had already united at 5 months. We noticed 15 cases of lateral thigh discomfort attributed to lateral migration of screws rubbing against tensor fascia lata. We noticed no cases of anterior thigh pain or femoral shaft fracture or nail breakage.

Table 6: Shortening.

\begin{tabular}{|lll|}
\hline $\begin{array}{l}\text { Shortening } \\
(\mathbf{c m})\end{array}$ & Number of patients & Percentage \\
\hline No shortening & 125 & 71.4 \\
\hline Upto $\mathbf{1 ~ c m}$ & 40 & 22.9 \\
\hline $\mathbf{1}$ to $\mathbf{2}$ cm & 10 & 5.7 \\
\hline Total & 175 & 100 \\
\hline
\end{tabular}

Table 7: Time of union.

\begin{tabular}{|lll|}
\hline Union in weeks & Number of patients & $\%$ \\
\hline $\mathbf{1 3 - 1 6}$ & 11 & 32.4 \\
\hline $\mathbf{1 7 - 2 0}$ & 15 & 44.1 \\
\hline $\mathbf{2 1 - 2 4}$ & 7 & 20.6 \\
\hline $\mathbf{2 5 - 3 0}$ & 1 & 2.9 \\
\hline Total & 34 & 100 \\
\hline
\end{tabular}

The average shortening was $0.34 \mathrm{~cm}$ ranging from 0 to 2 $\mathrm{cm}$ up to $1 \mathrm{~cm}$ shortening was seen in 8 patients due to severity of communition. $2 \mathrm{~cm}$ shortening was seen in 2 patients one patient with varus collapse and one with AVN, patient with varus collapse was given $2 \mathrm{cms}$ footwear.

Table 8: Functional outcome at end of 6 months.

\begin{tabular}{|lll|}
\hline Functional outcome & Number of patients & $\%$ \\
\hline Excellent & 40 & 22.9 \\
\hline Good & 85 & 48.6 \\
\hline Fair & 45 & 25.7 \\
\hline Poor & 5 & 2.8 \\
\hline Total & 175 & 100 \\
\hline
\end{tabular}

Table 9: Comparison between types of fracture and functional outcome.

\begin{tabular}{|c|c|c|}
\hline $\begin{array}{l}\text { Boyd \& Griffin } \\
\text { classification }\end{array}$ & $\begin{array}{l}\text { Number of } \\
\text { patients }\end{array}$ & $\begin{array}{l}\text { Functional outcome } \\
\text { (kyle's criteria) }\end{array}$ \\
\hline Type IV & 155 & $\begin{array}{l}\text { Excellent to good: } \\
110 \text { patients }(71 \%) \\
\text { Fair to poor: } 45 \\
\text { patients }(29 \%)\end{array}$ \\
\hline Type III & 20 & $\begin{array}{l}\text { Excellent to good: } 15 \\
\text { patients }(75 \%) \\
\text { Fair to poor: } 5 \\
\text { patients }(25 \%)\end{array}$ \\
\hline Total & 175 & $\begin{array}{l}\text { Excellent to good: } \\
125 \text { patients }(71.5 \%) \\
\text { Fair to poor: } 5- \\
\text { patients }(28.5 \%)\end{array}$ \\
\hline
\end{tabular}

Table 10: Comparision between severities of osteoporosis and functional outcome.

\begin{tabular}{|c|c|c|}
\hline $\begin{array}{l}\text { Singh index } \\
\text { of } \\
\text { osteoporosis }\end{array}$ & $\begin{array}{l}\text { Number } \\
\text { of } \\
\text { patients }\end{array}$ & $\begin{array}{l}\text { Functional outcome } \\
\text { (Kyle's criteria) }\end{array}$ \\
\hline $\begin{array}{l}\text { Grade VI to } \\
\text { IV } \\
\text { Mild to } \\
\text { Moderate }\end{array}$ & 145 & $\begin{array}{l}\text { Excellent to Good: } 110 \\
\text { patients }(76 \%) \\
\text { Fair to Poor: } 35 \text { patients } \\
(24 \%)\end{array}$ \\
\hline $\begin{array}{l}\text { Grade III to } \\
\text { I } \\
\text { Moderate to } \\
\text { Severe }\end{array}$ & 30 & $\begin{array}{l}\text { Excellent to Good: } 15 \\
\text { patients }(50 \%) \\
\text { Fair to Poor: } 15 \text { patients } \\
(50 \%)\end{array}$ \\
\hline Total & 175 & $\begin{array}{l}\text { Excellent to Good: } 125 \\
\text { patients }(71.5 \%) \\
\text { Fair to Poor: } 50 \text { patients } \\
(28.5 \%)\end{array}$ \\
\hline
\end{tabular}

\section{Duration of hospitalisation}

The average duration of hospital stay was 19.6 days (ranging from 6-30 days). 


\section{Follow up}

All patients were followed up at 1.5, 3, 4.5 and 6 months respectively. Patients were followed up, for a minimum of 6 months and maximum of 1 year.

\section{Radiological union}

Radiological union was said to be achieved, on the evidence of obliteration of fracture lines and trabecular continuity between the two fragments on anteroposterior and lateral $x$ rays in three cortices. The average time of union was 19.26 weeks, the range being from 15 to 30 weeks in 34 cases. Maximum number of fractures united between 17 to 20 weeks.

\section{Study case 1}

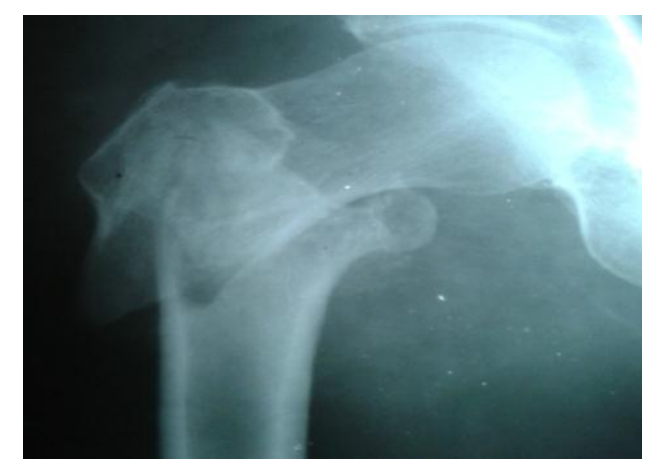

Figure 1: Pre-operative.

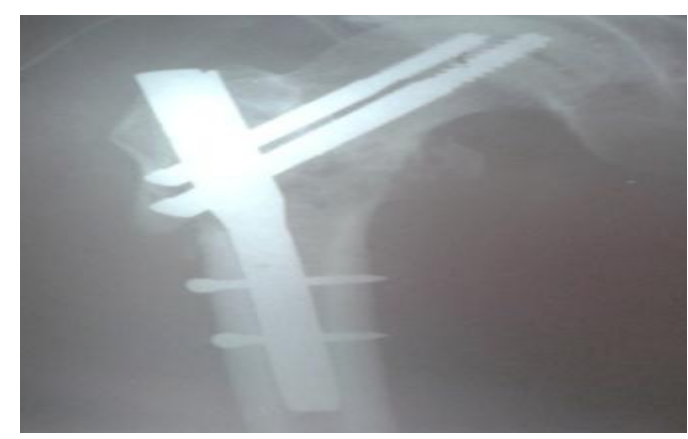

Figure 2: Post-operative.

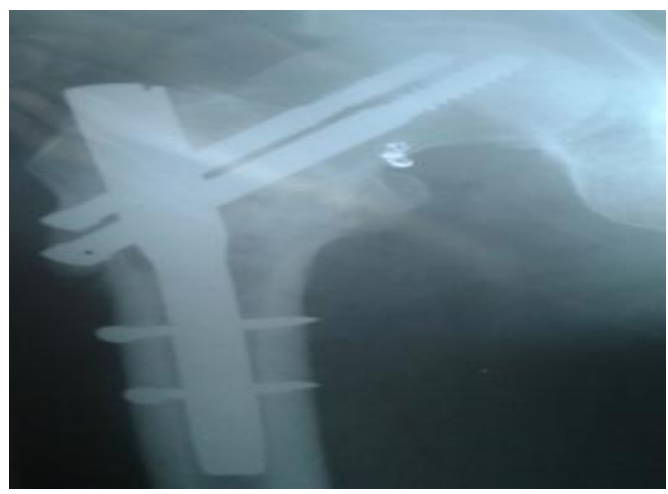

Figure 3: Post op 3 months x-ray.

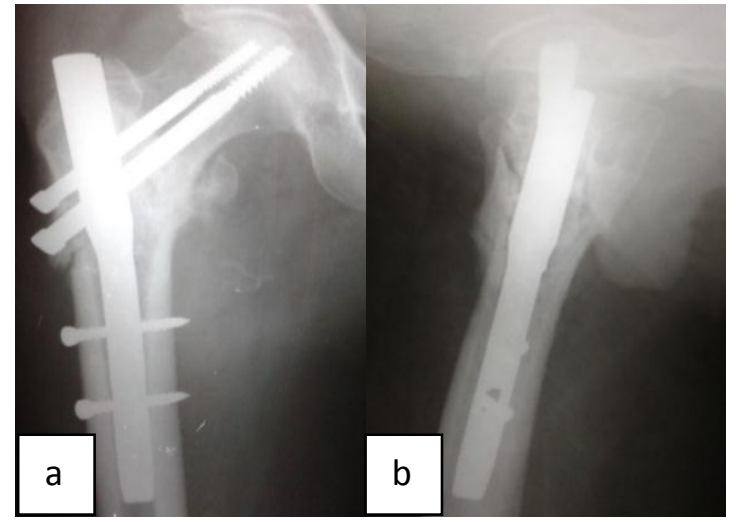

Figure 4 (a and b): Post op 6 months x-ray.

\section{Study case 2}

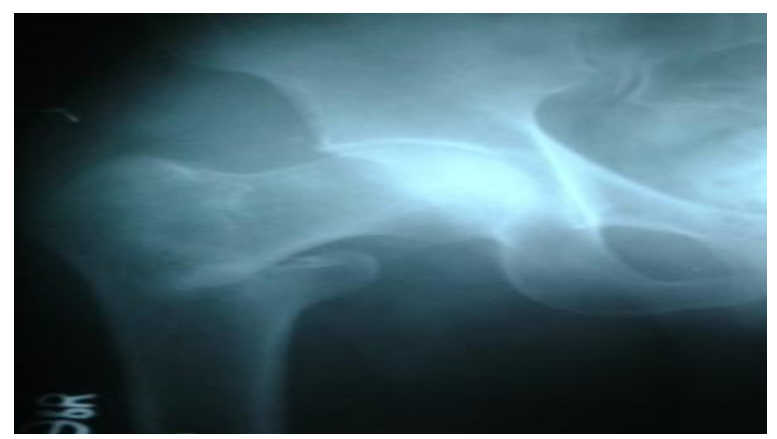

Figure 5: Pre op x-ray.

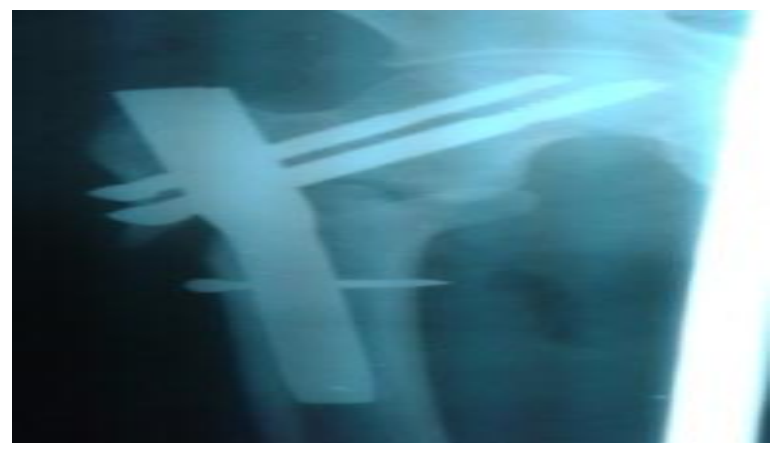

Figure 6: Post op x-ray.

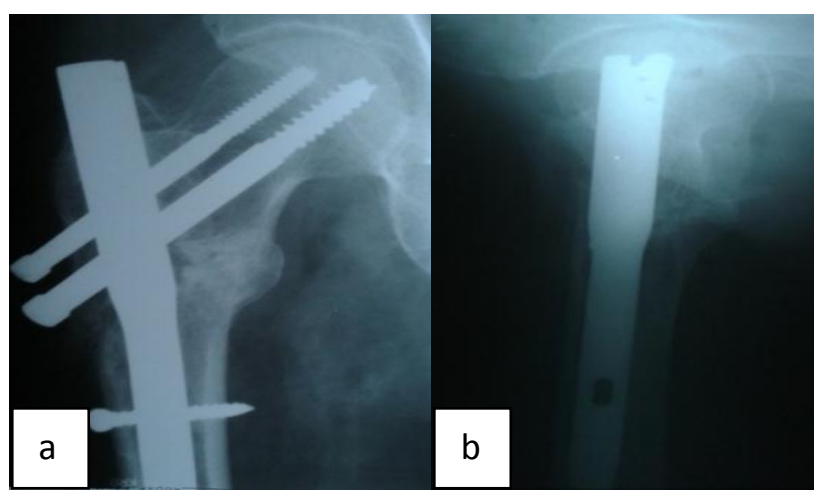

Figure 7 (a and b): Post op 6 months x-ray A.P and lateral view. 


\section{Complications}

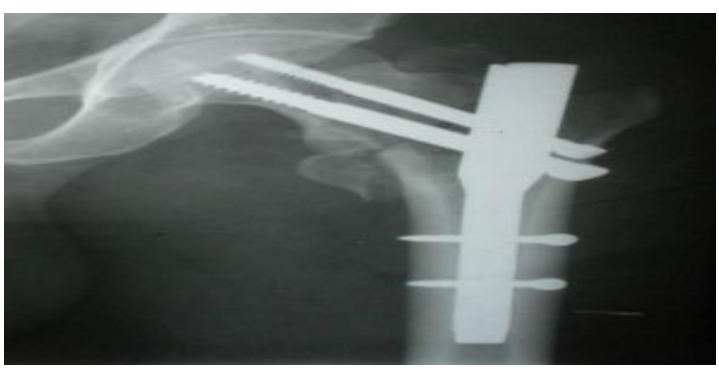

Figure 8: Gr. trochanter splintering.

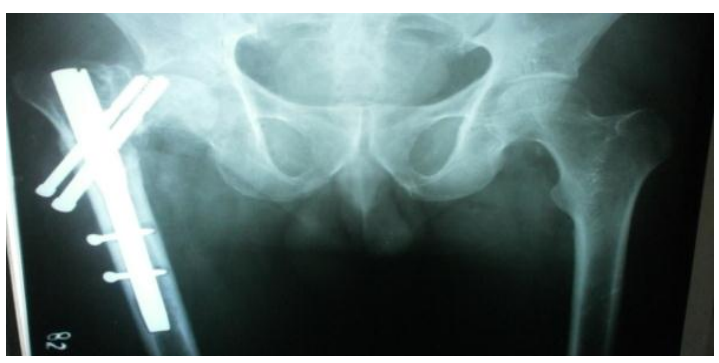

Figure 9: AVN and cut out of screws at 7 months.

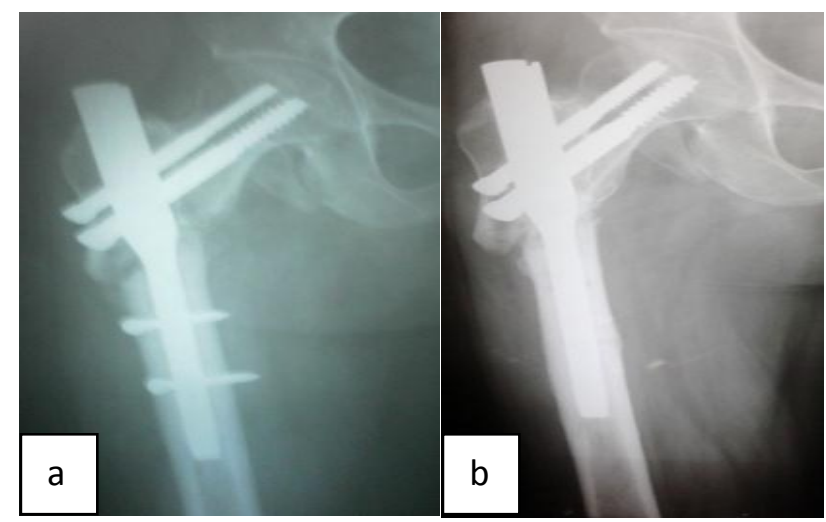

Figure 10 (a and b): Delayed union at 6 months and union at 7.5 months after dynamization.

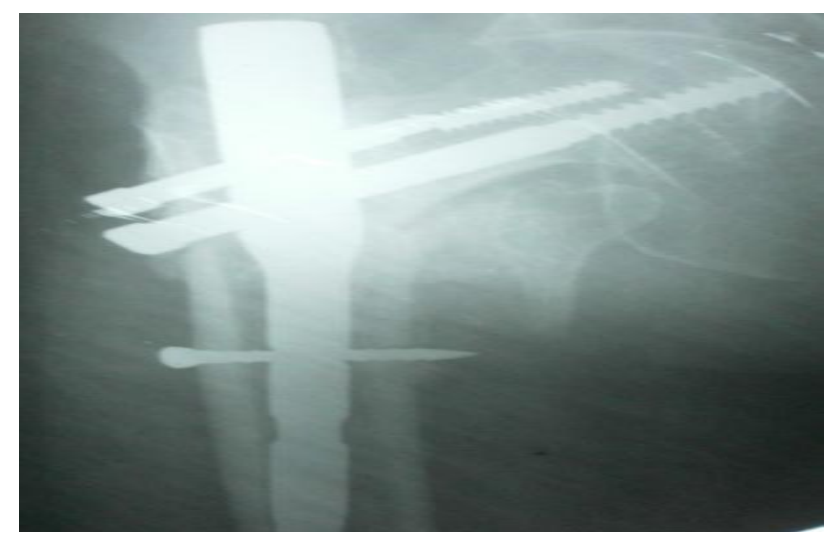

Figure 11: Varus malunion with Anti rotation screw breakage at 6 months.

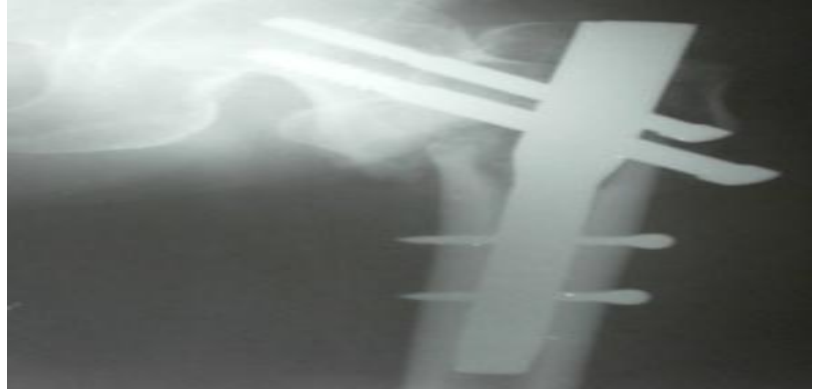

Figure 12: Compression screw back out at 1.5 months and varus collapse.

\section{DISCUSSION}

The surgical management is the preferred treatment for unstable fractures. Successful treatment of intertrochanteric fracture depends on surgeon independent variables like bone quality (osteoporosis) fracture pattern and fracture stability. Surgeon dependent variables like quality of fracture reduction, choice and placement of implant. ${ }^{16}$

The use of short PFN has become an attractive option as locally manufactured implants and instruments are available in India. Intramedullary nails have a biomechanical and biological advantage over standard compression hip screws, because of its location. ${ }^{17} \mathrm{~A}$ shorter lever arm of the intramedullary device can decrease tensile strain on the implant, so decreasing the risk of implant failure. Since this intramedullary fixation device incorporate a sliding hip screw the advantage of controlled fracture impaction is maintained. It also limits the amount of sliding and therefore limb shortening and deformity that can occur. It acts as a buttress to prevent medialisation of shaft. Immediate stability and early bony union were the most striking results from our study, which vindicated the overall efficacy of the close nailing technique and is in line with other study by Anglen et al. $^{18}$

Immediate stability had the concomitant advantage of restoration of full function of the extremity. In our study of 175 cases there were 40 cases (22.9\%) with excellent result, 85 cases $(48.6 \%)$ with good results, 45 cases $(25.7 \%)$ with fair result and 5 cases $(2.8 \%)$ with poor results. The functional outcome was evaluated using Kyle's criteria. Good to excellent results were seen in $71.5 \%$ of the patients of the average age of 65.9 years with unstable (Type III and IV) intertrochanteric fracture with grade V to III osteoporosis, according Kyle's criteria at 6 month. 100 patients (57\%) had returned to their preinjury functional level, functional outcomeswere almost similar in type-III and type-IV unstable fracture patterns. However functional outcome raised in various grades of osteoporosis. In mild to moderate osteoporosis excellent to good results were seen in $75 \%$ of patients. In moderate to severe osteoporosis, excellent to good result was seen in only $50 \%$ of patients. 
In our study average shortening was $0.34 \mathrm{~cm}$ ranging from 0 to $2 \mathrm{~cm}$. 125 patients had no shortening, up to 1 $\mathrm{cm}$ shortening was seen in 40 patients due to severity of communition, $2 \mathrm{~cm}$ shortening was in 10 patients, 5 patients with varus collapse.

In our study, many post-operative complication occurred, however most of these complications are related to operative technique, type of fracture, preoperative reduction, time to weight bearing, instruments and implant quality which can be brought down by preoperative planning.

\section{CONCLUSION}

In our study $71.5 \%$ elderly patients with an average age of 65.9 years had good to excellent outcome with an unstable (type III and IV) intertrochanteric fracture with grade V to III osteoporosis, 57\% had retrieved to preinjury functional level at 6 months.

Hence we conclude that short PFN provides good fixation for unstable intertrochanteric fracture if proper planning, good reduction and surgical techniques are followed, leading to high rate of bone union and minimal soft tissue damage specially for Asian patients with relatively small femora.

Funding: No funding sources

Conflict of interest: None declared

Ethical approval: The study was approved by the institutional ethics committee

\section{REFERENCES}

1. Kulkarni GS, Limaye R, Kulkarni M, Kulkarni S. Intertrochanteric fractures. Indian $\mathrm{j}$ orthop. 2008;40:16-23.

2. Koval KJ, Aharonoff GB, Rokito AS, Lyon T, Zuckerman JD. Paᄀtients with femoral neck and intertrochanteric fractures: Are they the same? Clin Orthop.1996;330:166-72.

3. Simpson AH, Varty K, Dodd CA. Sliding hip screws: modes of failure. Injury. 1989;20:227-31.

4. David A, van der Heyde D, Pommer A.Therapeutic possibilities in trochanteric fractures: safe-faststable. Orthopade. 2000;29:294-301.

5. Schipper IB, Steyerberg EW, Castelein RM,van der Heijden FH, den Hoed PT, Kerver AJ, et al. Treatment of unstable trochantericfractures: randomised comparision of the Gamma nail and the proximal femoral nail. J Bone Joint Surg Br. 2004;86:86-94.
6. Simmermacher RKJ, Bosch AM, Van der Werken C. The AO/ASIF- Proximal femoral nail: a new device for the treatment of unstable proximal femoral fractures. Injury. 1999;30:327-32.

7. Gadegone WM, Salphale YS. Short Proximal Femoral Nail Fixation for trochanteric Fractures. J Orthop Surg. 201;18(1):39-44.

8. Kyle RF, Gustilo RB, Premer RF. Analysis of six hundred and twenty-two intertrochanteric hip fractures. J Bone Joint Surg Am. 1979;61:216-21.

9. Boyd HB, Griffin LL. Classification and treatment of trochanteric fractures. Arch Surg. 1949;58:85366.

10. Parker MJ, Palmer CR. A new mobility score for predicting mortality after hip fracture. J Bone Joint Surg Br. 1993;75:797-8.

11. Pavelka T, Houcek P, Linhart M, Matejka J. Osteosynthesis of hip and femoral shaft fractures using the PFN-long. Acta Chir Orthop Traumatol Cech. 2007;74(2):91-8.

12. Wu CC, Shih CH, Lee MY, Tai CL. Biomechanical analysis of location of lag screw in treatment of unstable intertrochanteric fractures. $\mathrm{J}$ Trauma. 1996;41:699-702.

13. Canale ST, Beaty JH, editors. Campbell's Operative Orthopedics. 11th ed. Philadelphia: Mosby Elsevier; 2008.

14. Haidukewych GJ. Inter-trochanteric fractures: ten tips to improve results. J Bone Joint Surg Am. 2009;91:712-9.

15. Fogagnolo F, Kfuri M Jr, Paccola CA. Intramedullary fixation of pertrochanteric hip fractures with the short AOASIF proximal femoral nail. Arch Orthop Trauma Surg. 2004;124:31-7.

16. Kaufer H. Mechanics of the treatment of hip injuries. Clin Orthop. 1980;146:53-6.

17. Bucholz RW, Heckman JD, Koval KJ, Zukerman JD. Rockwood and Green's fractures in adults. 6th ed. Philadelphia: Lippincott Williams and Wilkins; 2005.

18. Anglen JU, Weinstein JN. Nail or plate fixation of inter-trochanteric fractures: changing pattern of practice. A review of the American Board of Orthopaedic Surgery database. J Bone Joint Surg Am. 2008;90:700-7.

Cite this article as: Jelani AR, Hathiwale MI, Mundewadi VV, Ahmed O. A clinical study to evaluate the effectiveness of the short proximal femoral nail in the management of unstable intertrochanteric fractures. Int J Res Orthop 2019;5:303-9. 